\title{
Evaluation of Bacillus thuringiensis to Control Tuta absoluta (Meyrick) (Lepidoptera: Gelechiidae) under Laboratory Conditions
}

\author{
Ghazwan Alsaedi ${ }^{1,2}$, Ahmad Ashouri ${ }^{*}{ }^{*}$, Reza Talaei-Hassanloui ${ }^{1}$ \\ ${ }^{1}$ Department of Plant Protection, College of Agriculture and Natural Resources, University of Tehran, Karaj, Iran \\ ${ }^{2}$ University of Basrah, Basrah, Iraq \\ Email:*ashouri@ut.ac.ir
}

How to cite this paper: Alsaedi, G., Ashouri, A. and Talaei-Hassanloui, R. (2017) Evaluation of Bacillus thuringiensis to Control Tuta absoluta (Meyrick) (Lepidoptera: Gelechiidae) under Laboratory Conditions. Agricultural Sciences, 8, 591-599. https://doi.org/10.4236/as.2017.87045

Received: January 29, 2017

Accepted: July 22, 2017

Published: July 25, 2017

Copyright $\odot 2017$ by authors and Scientific Research Publishing Inc. This work is licensed under the Creative Commons Attribution International License (CC BY 4.0).

http://creativecommons.org/licenses/by/4.0/

\begin{abstract}
The tomato leaf miner, Tuta absoluta (Meyrick) (Lepidoptera: Gelechiidae) is among the most destructive pests that attack tomato in many countries. In this study, the efficiency of three suspensions $\left(10^{6} ; 10^{5} ; 10^{4}\right.$ cell $\left./ \mathrm{ml}\right)$ of Bacillus thuringiensis var. Kurstaki was tested on T. absoluta larvae $1^{\text {st }}, 2^{\text {nd }}, 3^{\text {rd }}$ and $4^{\text {th }}$ instar was assessed to study the effect of these suspensions on larval mortality. Results showed that the concentration $10^{6} \mathrm{cell} / \mathrm{ml}$ resulted in the highest mortality of all instars larvae with an average mortality of $20 \%, 22.66 \%, 18.66 \%$ and $23.33 \%$ was recorded for the first, second, third and fourth instar, respectively. The greatest percentage of mortality occurred in the third day after the larvae fed with leaves treated with suspension B. thuringiensis.
\end{abstract}

\section{Keywords}

Bacillus thuringiensis var. Kurstaki, Three Suspensions, Tuta absoluta, Mortality, Four Larvae Instar

\section{Introduction}

Tomato (Solanum lycopersicum L.) is one of the most important solanaceous vegetable crops. The tomato plants are currently infested with many serious pests, recently the most destructive ones like $T$. absoluta. The tomato leaf miner T. absoluta (Lepidoptera: Gelechiidae) has long been considered as one of the most devastating pests of tomato and some other solanaceous plants in South America [1]. Recently, T. absoluta has started moving towards other continents, becoming a major threat to tomato production in Mediterranean region, the Middle East and some parts of Asia. The larvae of $T$. absoluta mine the leaves producing large galleries and burrow into the fruit, causing a substantial loss of 
tomato production in protected and open filed cultivations. The pest status of $T$. absoluta has been argued to arise mainly from its high fecundity, high mobility, migratory potential as well as its high propensity to rapidly develop resistance against different classes of pesticides [2] [3]. Apart from this, the mine-feeding nature of the larvae helps them to escape from direct contact with pesticides, thus reduce the efficacy of chemical control [4]. Biological control, as an alternative to chemical control, has been attempted in several South American and European countries [5].

Since the time of its initial detection, the pest has caused serious damages to tomato in invaded areas [6] and it is currently considered a key agricultural threat to European and North African tomato production. If no control measures are taken, the pest can cause up to $80 \%-100 \%$ yield losses by attacking leaves, flowers, stems and especially fruits [7].

To achieve an effective control of tomato leaf miner T. absoluta, different methods including the use of chemical pesticides, sex pheromones as well as biological control agents are utilised. Effectiveness of chemical control is limited due to insect's nature of damage (internal feeding) as well as its rapid capability of development of insecticide resistant strains. Apart from this, due to detrimental effects of synthetic pesticides on human health non-target organisms and the environment, the use of beneficial organisms has been encouraged as alternative to chemical methods. Currently, the use of biological control factors is largely under development and not ready to satisfactorily combat the pest. A variety of agents including predators, parasitoids, and entomopathogenic microorganisms have been argued to contribute in the regulation of T. absoluta population in the nature and efforts have been made to apply these agents for biological control of this pest in agricultural ecosystems. The soil dwelling bacterium Bacillus thuringiensis for example is the most important microorganism with entomopathogenic activity against certain insect orders. It is a ubiquitous, gram- positive and spore-forming bacterium which produces insecticidal crystal proteins during sporulation. Natural isolates of $B$. thuringiensis have been used as a biological pesticide since the 1950s for the control of certain insect species. The bacterium produces a specific crystalline protein inclusion ( $\delta$ endotoxin) that have insecticidal effects on insect pests of the orders Lepidoptera, Coleoptera, Diptera, Hymenoptera, Homoptera, Orthoptera and Mallophaga. This feature has made $B$. thuringiensis the most important biopesticide on the world market. However, what make this bacterium the most widely used biological agent among microorganisms is that the majority of its pathogenic strains possess specific activity against larvae of insect orders, with no or very low detrimental effects on the environment as well other non-target insects including predators and parasitoids [8] [9] [10] [11] [12].

Medeiros et al. [13] reported that B. thuringiensis var. Kurstaki have exhibited satisfactory efficacy against $T$. absoluta larval infestations in Spanish outbreaks. Furthermore, by conducting a series of laboratory, greenhouse, and open-field experiments, Gonzalez-Cabrera et al. [14] found evidence that B. thuringiensis is highly efficient in controlling T. absoluta, with the first instar larvae were the 
most susceptible, while susceptibility was lower in second and third instar larvae These authors have postulated that the damage of $T$. absoluta can be greatly reduced by spraying only $B$. thuringiensis with no need for chemical insecticides. To provide further support for this claim, in this study, we evaluated the efficiency of three doses of $B$. thuringiensis var. Karstaki for control of T. absoluta under laboratory conditions.

\section{Materials and Methods}

\section{Plants and Insects}

Tomato plants (Solanum lycopersicum L.) were grown in a greenhouse $\left(25^{\circ} \mathrm{C} \pm\right.$ $\left.5^{\circ} \mathrm{C}, 70 \% \pm 5 \% \mathrm{RH}, 16 \mathrm{~L}: 8 \mathrm{D}\right)$. Seeds originated from the University of Tehran, Department of Plant Protection, Ecology and Behavior Lab (Karaj, Iran). Five week old plants were used in the experiments. The plants were grown in small plastic pots ( $8 \mathrm{~cm}$ height, $9 \mathrm{~cm}$ diameter). A laboratory colony of $T$. absoluta was established by placing the tomato plants in cages containing approximately 30 ovipositing $T$. absoluta females for $24 \mathrm{~h}$, after this time, the plants were transferred to in rearing cages $\left(120 \times 75 \times 95 \mathrm{~cm}^{2}\right)$ and the developing larvae were weekly provided with fresh seedlings.

Used insects were collected from University of Tehran. Mated females of $T$. absoluta were obtained by pairing a virgin male and a virgin female moth. One day after mating $T$. absoluta females were used in the experiments.

\section{Formulation of $\mathrm{Bt}$}

The Bt formulation used in the experiments was B. thuringiensis sub sp. kurstaki $\left(10^{9}\right.$ cell/g) WP, Biolep, Biorun Company, Iran.

A series of dilutions were made to give suspension range of $10^{6}, 10^{5}$ and $10^{4}$ cell $/ \mathrm{ml}$.

\section{Treatment procedures}

Three suspensions $\left(10^{6} ; 10^{5} ; 10^{4} \mathrm{cell} / \mathrm{ml}\right)$ of $B$. thuringiensis were tested against each of four larval instars of T. absoluta.

For each bioassay, three fresh tomato leaves for each suspension were cut and sprayed by the suspensions, then transferred onto white clean paper for water evaporation and spread at the bottom of Petri dishes (12 cm diameter) with filter papers and supplied with moisture as needed. Ten newborn larvae of $T$. absoluta were randomly selected form the stock colony and released in each of the treated Petri dishes. B. thuringiensis treatment was conducted only once at the beginning of the bioassay, after that, the larvae were fed by untreated leaves. In control, the larvae were fed by untreated tomato leaves (sprayed by water only).

The same protocol was conducted for the $2^{\text {nd }}, 3^{\text {rd }}$ and $4^{\text {th }}$ instar larvae. The larvae were reared on untreated tomato leaves until they reached the age of interest; newly emerged instars were used for the bioassays.

For all assays, the larval mortality was evaluated daily within 72 hour after exposing to $B$. thuringiensis treated leaves. The percentage of mortality was corrected using Abbott's formula (1925): 


$$
\text { Corrected Mortality } \%=100 \times 1-\frac{\mathrm{NT}}{\mathrm{NC}}
$$

$(\mathrm{NT})=$ insect population after treatment

$(\mathrm{NC})=$ insect population in control

\section{Statistical analysis}

Data were analyzed using the statistical package for the Social Sciences (SPSS) version 21 (2012). Statistical comparison of data was carried out using one-way analysis of variance (ANOVA). For all analyses $P$ value less than 0.05 was considered significant.

\section{Result}

The efficiency of three suspensions of $B$. thuringiensis $\left(10^{6} ; 10^{5} ; 10^{4}\right.$ cell $\left./ \mathrm{ml}\right)$ was tested against different instars of $T$. absoluta under laboratory conditions.

The results showed that the concentration of $10^{6}$ cell $/ \mathrm{ml}$ was the most effective on all larval instars of T. absoluta followed by $10^{5}$ and $10^{4}$ cell $/ \mathrm{ml}$ concentrations.

The daily mortality (\%) of larval instars of T. absoluta feeding on Bt-treated tomato leaves has been summarized in Figures 1-4 respectively. After 24 hours, the mortality of first instar larvae was recorded as $20 \%, 7.33 \%$ and $7.33 \%$ for $10^{6}$; $10^{5} ; 10^{4}$ cell $/ \mathrm{ml}$ concentrations of Bt (Figure 1 ). The mortality increased gradually over time, such that $49.33 \%, 40.66 \%$, and $32 \%$ of treated larvae died after 72 hours following exposure to $10^{6} ; 10^{5} ; 10^{4} \mathrm{cell} / \mathrm{ml}$ of the bacterial suspension (Figure 1).

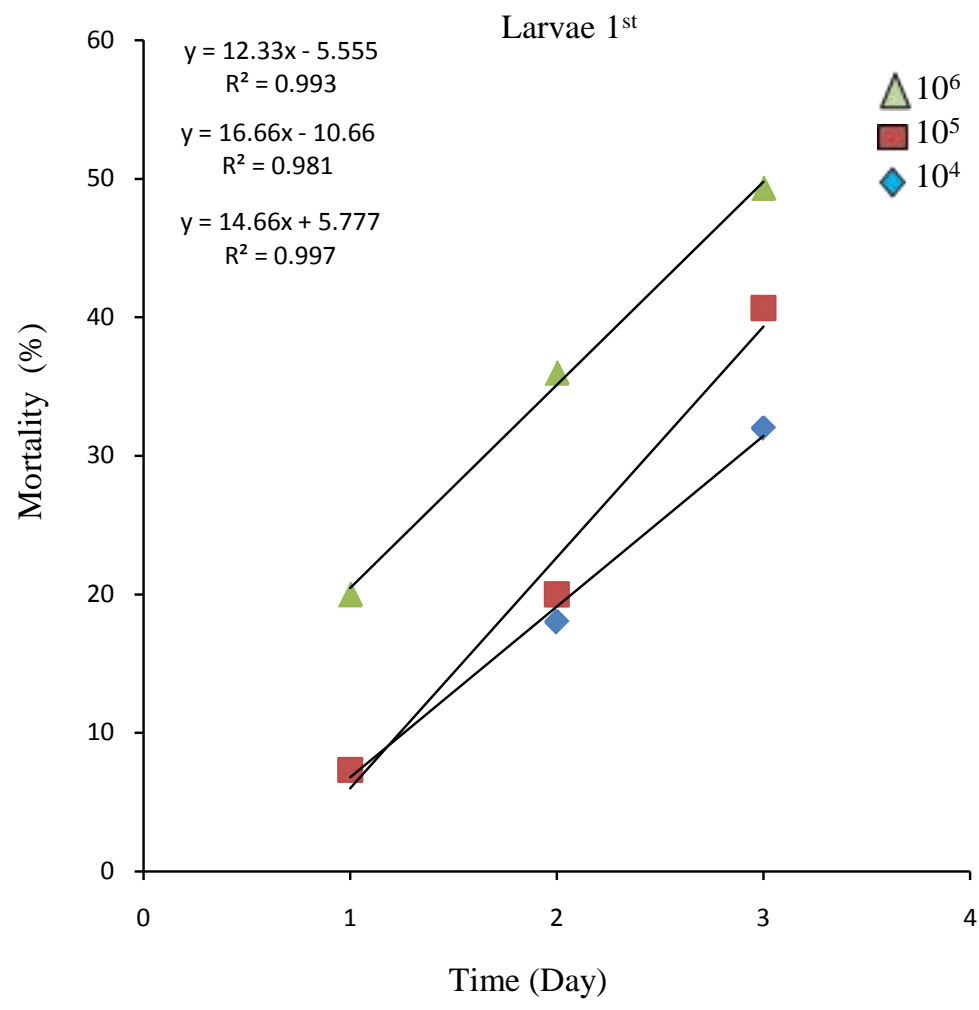

Figure 1 . The mortality of $T$. absoluta first instar when treated with three suspensions of $B$. thuringiensis. 


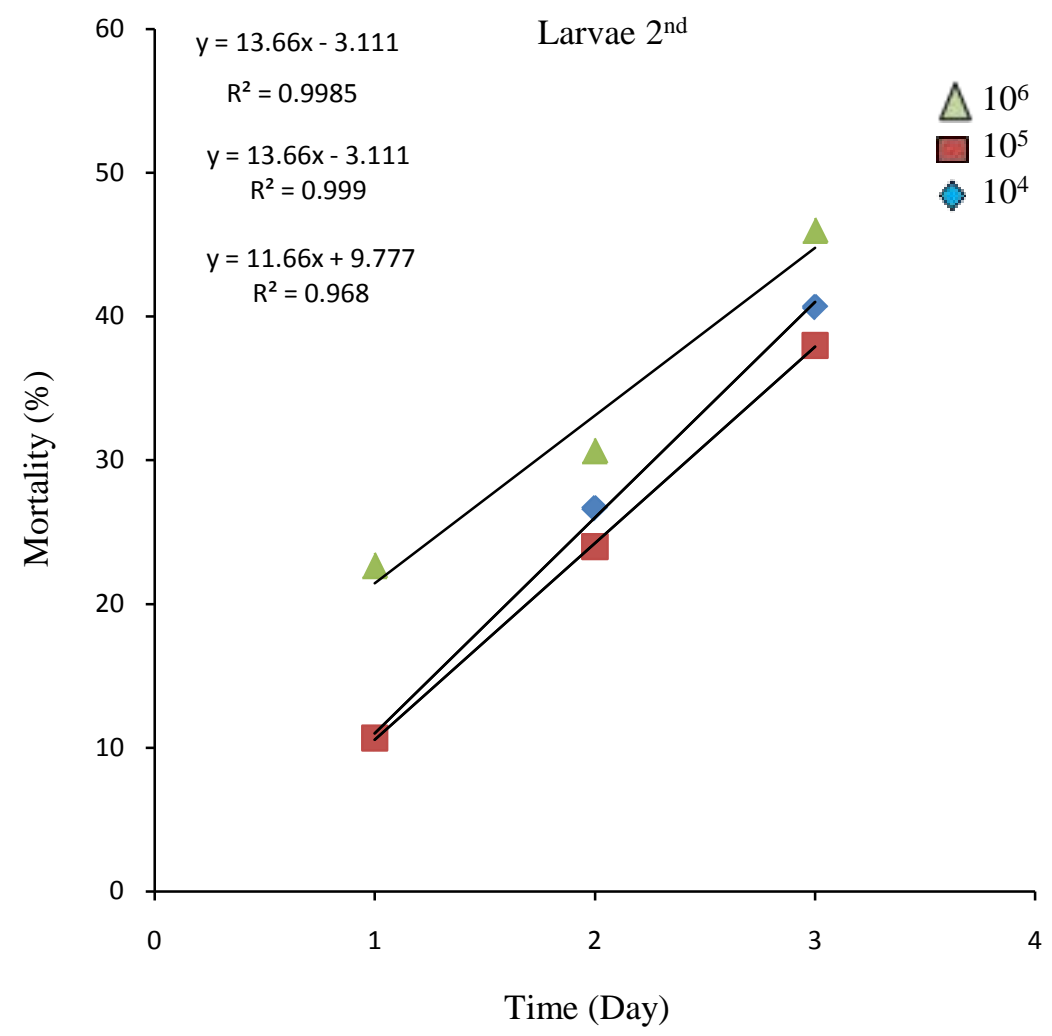

Figure 2. The mortality of $T$. absoluta second instar when treated with three suspensions of $B$. thuringiensis.

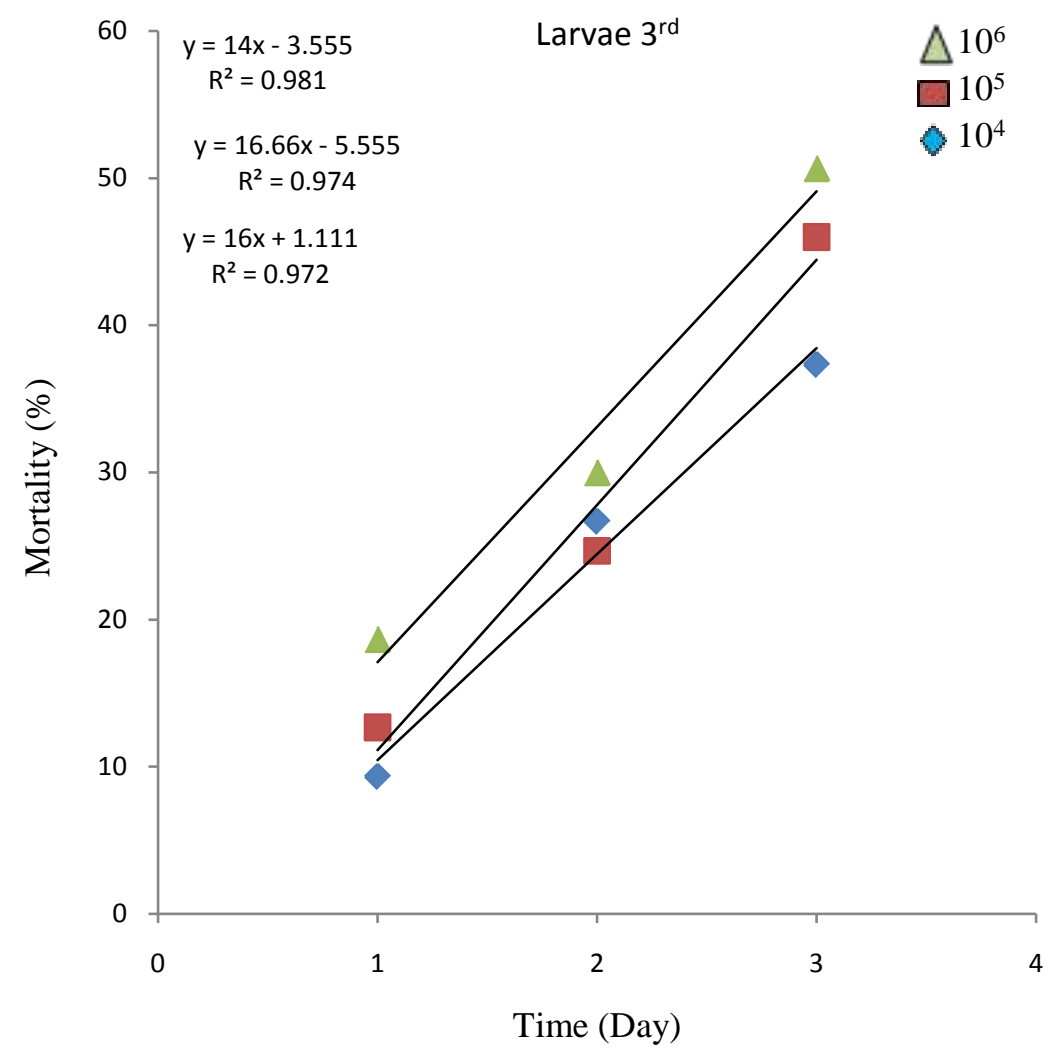

Figure 3. The mortality of T. absoluta third instar when treated with three suspensions of $B$. thuringiensis. 


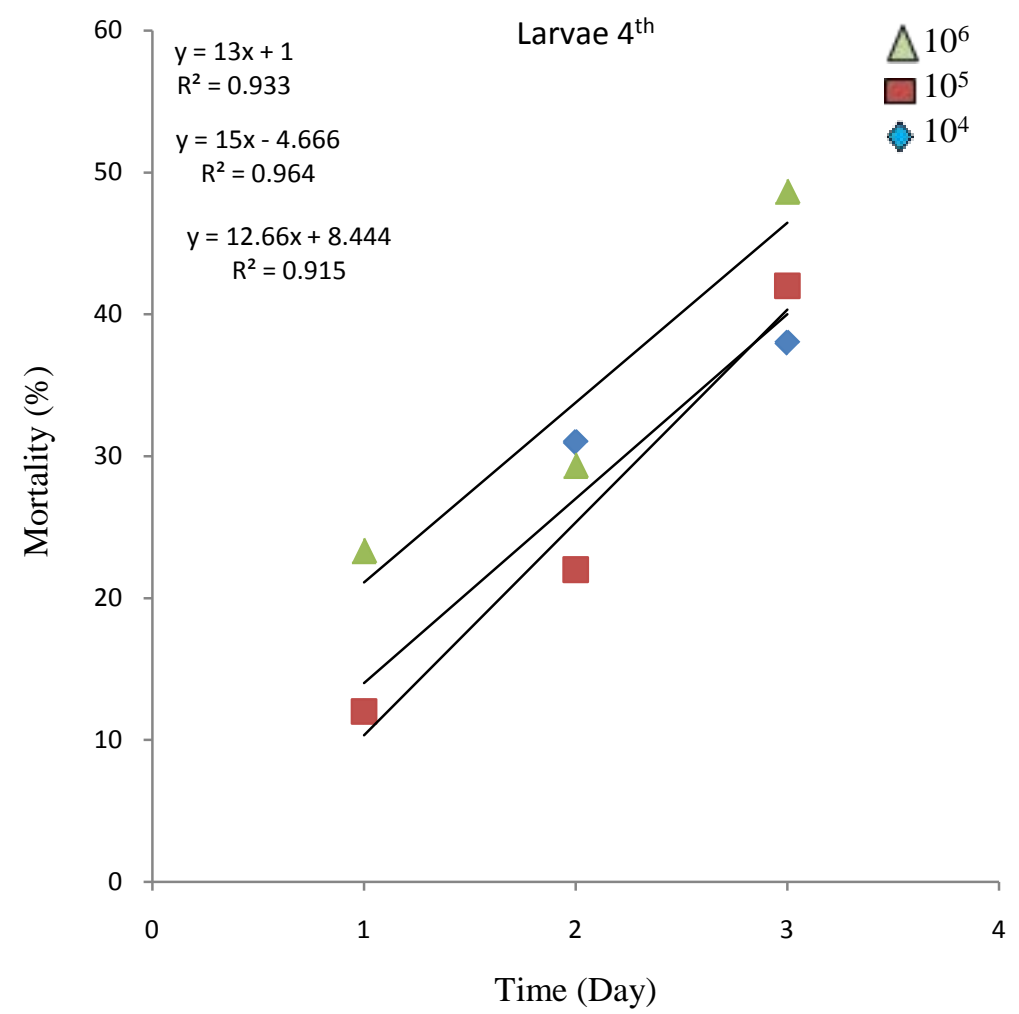

Figure 4. The mortality of $T$. absoluta fourth instar when treated with three suspensions of $B$. thuringiensis.

For the $2^{\text {nd }}$ instar larva of $T$. absoluta (Figure 2), the suspension of $B$. thuringiensis effect was evident by the first day for suspension $\left(10^{6} ; 10^{5} ; 10^{4}\right.$ cell $\left./ \mathrm{ml}\right)$ with corresponding mortalities $(22.66 \%, 10.66 \%$ and $10.66 \%)$ respectively. In addition the mortality values reached its maximum in the third day for suspension $\left(10^{6} ; 10^{5} ; 10^{4} \mathrm{cell} / \mathrm{ml}\right)$ and recorded $46 \%, 40.66 \%$ and $38 \%$ respectively. Therefore, it was obvious that the higher effective suspension of $B$. thuringiensis on second instar larvae of $T$. absoluta was $10^{6} \mathrm{cell} / \mathrm{ml}$ while the other two suspensions $\left(10^{5}\right.$ and $\left.10^{4} \mathrm{cell} / \mathrm{ml}\right)$ showed moderate effect.

For the $3^{\text {rd }}$ instar larva of $T$. absoluta (Figure 3), the suspensions of B. thuringiensis effect were evident by the $1^{\text {st }}$ day of exposure for the three suspension $\left(10^{6} ; 10^{5} ; 10^{4} \mathrm{cell} / \mathrm{ml}\right)$, with corresponding mortalities $(18.66 \%, 12.66 \%$ and $9.33 \%)$ respectively. Then, the values of the corrected mortalities of the $3^{\text {rd }}$ instar larvae increased gradually after the $3^{\text {rd }}$ day after exposure for the three suspensions to record $50.66 \%, 46 \%$, and $37.33 \%$ for the three suspensions respectively. Thus, it was evident that the higher effective suspension of $B$. thuringiensis on the $3^{\text {rd }}$ instar larvae of T. absoluta was $10^{6} \mathrm{cell} / \mathrm{ml}$ followed by $10^{5}$ and $10^{4}$.

Similar patterns of mortality was observed for the fourth instar larvae, where the mortality percentage of the larvae was recorded as $23.33 \%, 12 \%$ and $12 \%$ for larvae treated with $10^{6} ; 10^{5} ; 10^{4} \mathrm{cell} / \mathrm{ml}$ of the bacterium. The values of the corrected mortalities of $4^{\text {th }}$ instar larvae increased gradually after the $3^{\text {rd }}$ day with maximum mortality was recorded as $48.66 \%$ for $10^{6}$ cell $/ \mathrm{ml}, 42 \%$ for $10^{5}$ cell $/ \mathrm{ml}$ and $38 \%$ for $10^{4} \mathrm{cell} / \mathrm{ml}$. Thus, it was evident that the higher effective suspension 
of $B$. thuringiensis on $4^{\text {th }}$ instar larvae of T. absoluta was $10^{6} \mathrm{cell} / \mathrm{ml}$.

\section{Discussion}

The results of this study revealed high mortality of $T$. absoluta for the first, second, third and fourth larval instars fed with leaves treated with $B$. thuringiensis suspensions $\left(10^{6} ; 10^{5} ; 10^{4} \mathrm{cell} / \mathrm{ml}\right)$. According to these experiments, the highest percentage of mortality for all larval instars observed in larvae treated with $B$. thuringiensis suspension with a concentration of $10^{6} \mathrm{cell} / \mathrm{ml}$, followed by the suspension $10^{5} \mathrm{cell} / \mathrm{ml}$ and $10^{4} \mathrm{cell} / \mathrm{ml}$ which gave the lowest larval mortality.

These results are in agreement with those obtained by Cabello et al. [15] who reported that the effect of $B$. thuringiensis sub sp kurstaki on all larval instars of T. absoluta have exhibited satisfactory efficacy. Shalaby et al. [16] concerning the most effective concentration of $B$. thuringiensis, it was found that the higher concentration $\left(10^{7}\right)$ the higher mortality. Older instars were more susceptible to treatments than younger ones, as result of their longer stadia, beside their more sensitive integument and internal organs before and at the time of mortality. Larvae move in and out of the mines and galleries several times during their development and at that moment they are very vulnerable to infection by the bacteria [17]. On the other hand, larvae of the first and second instars remain in the leaf where oviposition took place. When they reach to the later instars there is more competition for food, and the larvae need to spread over the tomato plants [18]. Otherwise, Giustolin et al. [19] stated that; the higher mortality of neonate larvae, in comparison with the later instars can be explained by feeding behaviour differences. Also, neonate larvae scratch the leaf for $20 \pm 45 \mathrm{~min}$ before penetrating the mesophyll and are therefore exposed to a higher dose of bacterial spores and toxins. For second instar larvae as well, the low mortality on $\mathrm{Bt}$ treated Santa Clara leaves was probably related to the lack of leaf scratching as observed with neonates. For the third and fourth instar larvae, high mortality was probably due to greater leaf consumption since this instar was observed to consume the entire treated leaf, consequently ingesting a higher dose of the pathogen and its toxin.

Altogether, results of the current study confirm the larvicidal activity of the suspension of B. thuringiensis var. Kurstaki against T. absoluta and highlight it as a potential safe tool for using in integrated management of this pest in agricultural ecosystems. These results are in agreement with those obtained by $\mathrm{Ca}$ bello et al. [15] and Youssef and Hassan [18] whom reported that the effect of $B$. thuringiensis sub sp kurstaki on all larval instars have exhibited satisfactory efficacy against $T$. absoluta larval infestations. Commercially available formulations of $B$. thuringiensis strains are currently widely used for control of a variety of pests with economic importance, particularly the larval stage of many lepidopteran pests. The specificity of this agent, besides simplicity of mass production and formulation as well as its abundance in the nature make it an ideal option for use in combination with other biological control agents in management of $T$. absoluta. 


\section{Conclusion}

Generally, it could be concluded that the effect of $B$. thuringiensis application was dependent on the instar at which the larvae were fed on pathogen-treated leaves. In our experiment, the greatest percentage of mortality occurred on the all larval instar of $T$. absoluta in the third day. In addition, the most effective suspension of $B$. thuringiensis was $10^{6} \mathrm{cell} / \mathrm{ml}$ the higher mortality.

\section{References}

[1] Barrientos, Z.R., Apablaza, H.J., Norero, S.A. and Estay, P.P. (1998) Threshold Temperature and Thermal Constant for Development of the South American Tomato Moth, T. absoluta (Lepidoptera, Gelechiidae). Ciencia e Investigación Agraria, 25, 133-137.

[2] Siqueira, H.A., Guedes, R.N. and Picanco, M.C. (2000) Insecticide Resistance in Populations of Tuta absoluta (Lepidoptera: Gelechiidae). Agricultural and Forest Entomology, 2, 147-153. https://doi.org/10.1046/j.1461-9563.2000.00062.x

[3] Lietti, M.M.M., Botto, E. and Alzogaray, R.A. (2005) Insecticide Resistance in Argentine Populations of Tuta absoluta (Meyrick) (Lepidoptera: Gelechiidae). Neotropical Entomology, 34, 113-119. https://doi.org/10.1590/S1519-566X2005000100016

[4] Urbaneja, A., Sanchez, E. and Stansly, P.A. (2007) Life History of Eretmocerus mundus, a Parasitoid of Bemisia tabaci, on Tomato and Sweet Pepper. BioControl, 52, 25-39. https://doi.org/10.1007/s10526-006-9014-8

[5] Parra, J.R.P. and Zucchim, R.A. (2004) Trichogramma in Brazil: Feasibility of Use after Twenty Years of Research. Neotropical Entomology, 33, 271-281. https://doi.org/10.1590/S1519-566X2004000300001

[6] Germain, J.F., Lacordaire, A.I., Concquempot, C., Ramel, J.M. and Oudard, E. (2009) Unnouveau ravageur de la tomate en France: Tuta absoluta. PHM-Revue Horticole, 512, 37-41.

[7] Lopez, E. (1991) Polilla del tomate: Problema critico para la rentabil-idad del cultivo de verano. Empresa y Avance Agricola, 1, 6-7.

[8] Bernhard, K., Jarrett, P., Meadows, M., Butt, J., Ellis, D.J., Roberts, G.M., Pauli, S., Rodgers, P. and Burges, H.D. (1997) Natural Isolates of Bacillus thuringiensis. Worldwide Distribution, Characterization, and Activity against Insect Pest. Journal of Invertebrate Pathology, 70, 59-68.

[9] Schnepe, E., Crickmore, N., van Rie, J., Lerclus, D., Baum, J., Feitelson, J., Zeigler, D.R. and Dean, D.H. (1998) Bacillus thuringiensis and Its Pesticidal Crystal Proteins. Microbiology and Molecular Biology Reviews, 62, 775-806.

[10] Mizuki, E., Ohba, M., Akao, T., Yamashita, S., Saitoh, H. and Park, Y.S. (1999) Unique Activity Associated with Non-Insecticidal Bacillus thuringiensis Parasporal Inclusions: In Vitro Cell-Killing Action on Human Cancer Cells. Journal of Applied Microbiology, 86, 477-486. https://doi.org/10.1046/j.1365-2672.1999.00692.x

[11] Xu, Z., Yao, B., Sun, M. and Yu, Z. (2004) Protection of Mice Infected with Plasmodium berghei by Bacillus thuringiensis Crystal Proteins. Parasitology Research, 92, 53-57. https://doi.org/10.1007/s00436-003-0990-7

[12] Pazos, L. and Salamanca, C. (2007) Three-Dimensional Structure of Bacillus thuringiensis Toxins. Acta Biológica Colombiana, 12, 19-32.

[13] Medeiros, N.A., Burnette, D.T. and Forscher, P. (2006) Myosin II Functions in Actin-Bundle Turnover in Neuronal Growth Cones. Nature Cell Biology, 8, 216-226. 
https://doi.org/10.1038/ncb1367

[14] Gonzalez-Cabrera, J., Molla, O., Monton, H. and Urbaneja, A. (2011) Efficacy of Bacillus thuringiensis (Berliner) for Controlling the Tomato Borer, Tuta absoluta (Meyrick) (Lepidoptera: Gelechiidae). BioControl, 56, 71-80.

https://doi.org/10.1007/s10526-010-9310-1

[15] Cabello, T., Gallego, J.R., Vila, E., Soler, A., del Pino, M., Carnero, A., Hernandez, S. and Polaszek, A. (2009) Biological Control of the South American Tomato Pinworm, Tuta absoluta (Lepidoptera: Gelechiidae), with Releases of Trichogramma achaeae (Hymenoptera: Trichogrammatidae) on Tomato Greenhouse of Spain. IOBC-WPRS Bulletin, 49, 225-230.

[16] Shalaby, H.H., Faragalla, F.H., El-Saadany, H.M. and Ibrahim, A.A. (2013) Efficacy of Three Entomopathogenic Agents for Control the Tomato Borer, Tuta absoluta (Meyrick) (Lepidoptera: Gelechiidae). Nature and Science, 11, 63-72.

[17] Harizanova, V., Stoeva, A. and Mohamedova, M. (2009) Tomato Leaf Miner, Tuta absoluta (Povolny) (Lepidoptera: Gelechiidae)—First Record in Bulgaria. Agriculture and Environment, 1, 95-98.

[18] Youssef, N.A. and Hassan, G.M. (2013) Bioinsecticide Activity of Bacillus thuringiensis Isolates on Tomato Borer, Tuta absoluta (Meyrick) and Their Molecular Identification. African Journal of Biotechnology, 12, 3699-3709.

[19] Giustolin, T.A., Vendramim, J.D., Alves, S.B., Vieira, S.A. and Pereira, R.M. (2001) Susceptibility of Tuta absoluta (Meyrick) (Lep., Gelechiidae) Reared on Two Species of Lycopersicon to Bacillus thuringiensis var. kurstaki. Journal of Applied Entomology, 125, 551-556. https://doi.org/10.1046/j.1439-0418.2001.00579.x

\section{Submit or recommend next manuscript to SCIRP and we will provide best service for you:}

Accepting pre-submission inquiries through Email, Facebook, LinkedIn, Twitter, etc. A wide selection of journals (inclusive of 9 subjects, more than 200 journals)

Providing 24-hour high-quality service

User-friendly online submission system

Fair and swift peer-review system

Efficient typesetting and proofreading procedure

Display of the result of downloads and visits, as well as the number of cited articles

Maximum dissemination of your research work

Submit your manuscript at: http://papersubmission.scirp.org/

Orcontact as@scirp.org 